\title{
Faktor-Faktor Yang Mempengaruhi Status Perkembangan Balita Di Sleman Yogyakarta
}

\author{
Dini Makrufiyani ${ }^{1}$, Dyah Noviawati Setya Arum ${ }^{2}$, Nanik Setiyawati ${ }^{3}$ \\ ${ }^{1}$ Puskesmas Seyegan - Prop. D.I. Yogyakarta - Indonesia 55293 \\ ${ }^{2}$ Poltekkes Kemenkes Yogyakarta, MJ III/304, Jl. Mangkuyudan, Mantrijeron, Kec. Mantrijeron, Kota Yogyakarta - \\ Prop. D.I. Yogyakarta - Indonesia 55143 \\ 3Poltekkes Kemenkes Yogyakarta, MJ III/304, Jl. Mangkuyudan, Mantrijeron, Kec. Mantrijeron, Kota Yogyakarta - \\ Prop. D.I. Yogyakarta - Indonesia 55143, nanikyogya@gmail.com
}

\begin{tabular}{|c|c|}
\hline Kata kunci: & ABSTRAK \\
\hline $\begin{array}{l}\text { Status } \\
\text { perkembangan }\end{array}$ & $\begin{array}{l}\text { Latar Belakang : Masa lima tahun pertama kehidupan merupakan masa yang } \\
\text { sangat peka terhadap lingkungan dan berlangsung sangat pendek serta tidak } \\
\text { dapat terulang. Tujuan : Mengetahui faktor-faktor yang mempengaruhi status }\end{array}$ \\
\hline Balita & $\begin{array}{l}\text { perkembangan balita usia 1-3 tahun di Sleman Yogyakarta. Metode : Penelitian } \\
\text { ini menggunakan desain cross sectional. Subjek penelitian ini adalah } 90 \text { balita }\end{array}$ \\
\hline $\begin{array}{l}\text { Pendidikan } \\
\text { orang tua }\end{array}$ & $\begin{array}{l}\text { usia 1-3 tahun di wilayah Puskesmas Gamping II Sleman dengan teknik } \\
\text { consecutive sampling. Instrumen yang digunakan adalah Kuesioner Pra } \\
\text { Skrining Perkembangan (KPSP). Analisis data yang digunakan adalah uji chi } \\
\text { square dan regresi logistik. Hasil : Faktor yang berhubungan secara signifikan } \\
\text { dengan status perkembangan balita adalah status gizi balita } \mathrm{p}=0,024 \text {, } \\
\text { pendapatan orang tua p=0,024, dan pendidikan orang tua } \mathrm{p}=0,006 \text {. Serta faktor } \\
\text { yang paling mempengaruhi status perkembangan balita adalah pendidikan } \\
\text { orang tua (koef- } \beta \text { 1,396, p-value } 0,015 \text {, PR 4,039, CI 95\% 1,312-12,433). } \\
\text { Kesimpulan : Pendidikan orang tua adalah faktor yang paling mempengaruhi } \\
\text { status perkembangan balita usia } 1-3 \text { tahun. }\end{array}$ \\
\hline Key words: & ABSTRACT \\
\hline $\begin{array}{l}\text { Development } \\
\text { status }\end{array}$ & $\begin{array}{l}\text { Background: The first five years of child's life is a very crucial period where they are } \\
\text { very sensitive towards their environment and it happens in unrepeatable short of period. } \\
\text { Objectives : To determine factors affecting the development status of } 1 \text { to } 3 \text { years old }\end{array}$ \\
\hline Toddler & $\begin{array}{l}\text { toddler at Sleman, Yogyakarta. Method: This was a cross sectional design study. } \\
\text { Samples are } 90 \text { toddlers aged } 1 \text { to } 3 \text { years at Gamping II Public Health Center, Sleman }\end{array}$ \\
\hline Parents education & $\begin{array}{l}\text { Yogyakarta were included using consecutive sampling. To find the development of } \\
\text { toddlers development, Pre-Screening Questionnaire Development (KPSP) was used. } \\
\text { Result: The factors that correlate significantly with the toddlers' developmental status } \\
\text { was toddler nutrition } p=0.024 \text {, parents income } p=0.024 \text {, and parents education } p=0.006 \text {. } \\
\text { The most significant factor affecting toddlers developmental status was parents } \\
\text { education (koef- } \beta 1.396, p \text {-value } 0.015, P R 4.039, \text { CI 95\% } 1.312-12.433 \text { ). Conclusion: } \\
\text { Parents education is the most significant factor affecting the development status of } \\
\text { toddlers between the ages } 1-3 \text {. }\end{array}$ \\
\hline
\end{tabular}

This is an open access article under the CC-BY-SA license. 


\section{Pendahuluan}

Derajat kesehatan suatu bangsa dapat dilihat dari derajat kesehatan anak. Anak memiliki kemampuan yang dapat dikembangkan menjadi manusia berkualitas yang dapat meneruskan pembangunan bangsa. [1], [2] Setiap tahun, lebih dari 200 juta anak yang berusia kurang dari 5 tahun menunjukkan keterlambatan perkembangan dan $86 \%$ kasus tersebut terjadi di negara berkembang.[3] Sekitar $43 \%$ anak di negara berkembang dikhawatirkan akan mengalami gangguan perkembangan.[4] Tidak terpenuhinya potensi perkembangan anak akan menyebabkan kemampuan anak tersebut di usia dewasa berkurang sehingga akan berimplikasi pada perkembangan suatu bangsa.[5]

Masa lima tahun pertama kehidupan anak merupakan masa yang sangat kritis terhadap perkembangannya. Masa ini berlangsung sangat pendek serta tidak dapat diulangi lagi. Masa ini berlangsung sebagai "masa keemasan" (golden period), "jendela kesempatan" (window opportunity) dan "masa kritis" (critical period). Periode tiga tahun pertama pada masa balita merupakan periode emas pertumbuhan fisik, intelektual, mental, dan emosional anak. Pertumbuhan dan perkembangan otak paling cepat terjadi pada 3 tahun pertama sehingga menjadi perhatian khusus untuk pengukuran rutin dan pemberian nutrisi.[1] Usia toddler terjadi antara usia 1 sampai 3 tahun. Keberhasilan menguasai tugas-tugas perkembangan pada usia toddler membutuhkan dasar yang kuat selama masa pertumbuhan dan memerlukan bimbingan dari orang lain terutama orang tua.[6] Pada tahun 2013 berdasarkan data IDAI diperkirakan 5-10\% anak di Indonesia mengalami keterlambatan perkembangan.[7]

Gangguan perkembangan sekecil apapun pada masa balita apabila tidak terdeteksi dan tidak ditangani dengan baik akan berdampak buruk.[1] Jika keterlambatan tidak diketahui lebih cepat akan sangat berpengaruh pada perkembangan motorik anak selanjutnya, karena perkembangan anak memiliki rangkaian tahapan yang berurutan.[8] Salah satu upaya untuk mengetahui adanya penyimpangan perkembangan bayi dan balita yaitu dengan deteksi dini penyimpangan perkembangan. Melalui deteksi dini dapat diketahui adanya masalah perkembangan anak sehingga pemulihannya dapat dilakukan lebih awal dan akhirnya tumbuh kembang anak yang dapat berlangsung dengan optimal.[1] Perkembangan anak sangat penting karena anak dengan perkembangan yang terlambat akan sulit mengejar ketertinggalan dan akan mempengaruhi kehidupan anak di masa mendatang.[9] RSUP DR. Sardjito Yogyakarta yang merupakan rumah sakit rujukan di Propinsi Daerah Istimewa Yogyakarta, dari bulan Januari sampai Maret 2016 terdapat 60,7\% balita yang mengalami keterlambatan perkembangan.[10]

Perkembangan seorang anak dipengaruhi oleh beberapa hal, antara lain faktor genetik dan lingkungan. Faktor lingkungan yang dapat mempengaruhi perkembangan anak meliputi lingkungan pranatal, perinatal, dan postnatal. Yang termasuk faktor lingkungan pranatal yaitu riwayat gizi ibu saat hamil, mekanis, toksin kimia. Lingkungan perinatal seperti Berat Badan Lahir Rendah (BBLR) sedangkan lingkungan posnatal adalah faktor biologis (ras, jenis kelamin, status gizi), faktor fisik, faktor psikososial, dan faktor keluarga (pekerjaan/pendapatan keluarga, pendidikan ayah/ibu, jumlah saudara).[2] Berdasarkan Profil Kesehatan Sleman tahun 2016 menunjukkan bahwa Puskesmas Gamping II mempunyai jumlah balita dengan status gizi buruk (kurus) terbanyak di Kabupaten Sleman yaitu sebesar 6,68\%.[11]

Status gizi merupakan faktor yang paling mempengaruhi perkembangan motorik anak.[12] Variabel yang berhubungan dengan perkembangan balita adalah pendidikan orang tua, pendapatan orang tua, jumlah anak $\geq 3$, BBLR.[13] Jenis kelamin, berat lahir, pendidikan ibu, dan tempat persalinan memiliki hubungan yang signifikan dengan perkembangan balita.[14] Namun penelitian lain menunjukkan hanya faktor pendidikan ibu yang mempengaruhi 
perkembangan anak. Faktor pendapatan keluarga, jumlah saudara, interaksi orang tua dengan anak tidak mempengaruhi perkembangan anak.[15]

Beberapa penelitian menunjukkan perkembangan dipengaruhi oleh beberapa faktor. Berdasarkan identifikasi masalah tersebut peneliti tertarik melakukan penelitian dengan topik faktor-faktor yang mempengaruhi status perkembangan balita usia 1-3 tahun di wilayah Puskesmas Gamping II Sleman. Tujuan dari penelitian ini adalah untuk mengetahui faktorfaktor yang mempengaruhi status perkembangan balita usia1-3 tahun meliputi berat badan lahir balita, status gizi balita, pendapatan orang tua, pendidikan orang tua, dan jumlah saudara balita. Manfaat penelitian ini diharapkan memperkaya bukti empiris, menambah informasi dan meningkatkan motivasi dalam stimulasi dan deteksi dini perkembangan, serta referensi mengenai faktor-faktor yang mempengaruhi status perkembangan balita usia 1-3 tahun di wilayah Puskesmas Gamping II Sleman Yogyakarta.

\section{Metode}

Penelitian ini dilaksanakan dengan metode observasional analitik dan desain penelitian Cross Sectional. Populasi pada penelitian ini adalah seluruh balita usia 1-3 tahun dengan orang tuanya di Desa Banyuraden wilayah Puskesmas Gamping II Sleman. Penelitian ini dilakukan pada bulan April 2018 di 7 Posyandu Desa Banyuraden wilayah Puskesmas Gamping II Kabupaten Sleman. Pengambilan sampel dengan teknik consecutive sampling berjumlah 90 orang. Kriteria inklusi adalah balita yang tinggal dengan kudua orang tuanya dan bersedia berpartisipasi. Kriteria eksklusi adalah balita yang sedang menjalani pengobatan atau sedang sakit infeksi saat penelitian seperti TBC, DB, Malaria, Campak, dan DPT dan balita yang mempunyai kelainan kongenital.

Pengumpulan data pada penelitian ini dengan data primer melalui pengukuran status perkembangan menggunakan Kuesioner Pra Skrining Perkembangan (KPSP). Penilaian status gizi dilakukan dengan penimbangan berat badan dan pengukuran tinggi badan. Serta wawancara kepada orang tua mengenai berat badan lahir balita, pendapatan orang tua, dan pendidikan orang tua. Analasis data yang digunakan adalah analisis univariat dengan distribusi frekuensi, analisis bivariat dengan chi-square, dan analisis multivariat dengan regresi logistik menggunakan bantuan SPSS.

\section{Hasil Dan Pembahasan}

Penelitian ini dilakukan di Wilayah Puskesmas Gamping II yang terdiri dari 54 posyandu balita dengan jumlah balita 3222 per Desember 2017. Penelitian dilakukan di 7 posyandu Desa Banyuraden. Sampel yang digunakan adalah 90 subjek penelitian. Subjek dalam penelitian ini adalah balita usia 1-3 tahun dengan ibunya yang berkunjung ke posyandu wilayah Puskesmas Gamping II.

Berdasarkan tabel 1, sebagian besar responden adalah memiliki status perkembangan sesuai sebanyak 67 subjek (74,4\%), masih adanya 23 subjek (25,6\%) yang memiliki status perkembangan tidak sesuai. Hal ini menunjukkan perlu adanya peran bidan dalam memberikan wawasan kepada orang tua untuk memberikan stimulasi perkembangan kepada balitanya. Adapun Jenis kelamin antara responden laki-laki dan perempuan hampir sama jumlahnya. Mayoritas responden tidak BBLR dan 74 subjek (82,2\%) responden dengan status gizi normal. Mayoritas orang tua balita memiliki pendapatan dan pendidikan dalam kategori tinggi, sedangkan untuk jumlah saudara balita mayoritas mempunyai saudara 0-1 orang sebanyak 77 subjek $(85,6 \%)$. 
Vol.22, No. 1, (Maret) 2020, pp. 23 - 31

Tabel 1. Distribusi Frekuensi Karakteristik Subjek Penelitian

\begin{tabular}{lcc}
\multicolumn{1}{c}{ Variabel } & $\mathrm{n}$ & $\%$ \\
\hline Status Perkembangan Balita & & \\
$\quad$ Tidak Sesuai & 23 & 25,6 \\
$\quad$ Sesuai & 67 & 74,4 \\
\hline Jenis Kelamin Balita & & \\
$\quad$ Laki-Laki & 44 & 48,9 \\
$\quad$ Perempuan & 46 & 51,1 \\
\hline Berat Badan Lahir Balita & 6 & \\
$\quad$ BBLR & 84 & 6,7 \\
$\quad$ Tidak BBLR & & 93,3 \\
\hline Status Gizi Balita & 16 & 17,8 \\
$\quad$ Tidak Normal & 74 & 82,2 \\
$\quad$ Normal & & \\
\hline Pendapatan Orang Tua & 35 & 38,9 \\
$\quad$ Rendah & 55 & 61,1 \\
$\quad$ Tinggi & & \\
\hline Pendidikan Orang Tua & 19 & 21,1 \\
$\quad$ Rendah & 71 & 78,9 \\
$\quad$ Tinggi & & \\
Jumlah Saudara Balita & 13 & 14,4 \\
$\quad$ 1 & 77 & 85,6 \\
$\quad 0-1$ & &
\end{tabular}

Berdasarkan Tabel 2, terlihat bahwa faktor-faktor yang berhubungan dengan status perkembangan balita ( $\mathrm{p}$-value $<0,05)$ adalah status gizi balita $(\mathrm{p}=0,024)$, pendapatan orang tua $(\mathrm{p}=0,024)$, dan pendidikan orang tua $(\mathrm{p}=0,006)$. Berat badan lahir balita dan jumlah saudara tidak berhubungan dengan status perkembangan balita. Responden dengan BBLR memiliki prosentase yang sama antara yang memiliki perkembangan sesuai dan tidak sesuai, sedangkan untuk responden yang tidak BBLR mayoritas memiliki perkembangan yang sesuai. Demikian pula untuk status gizi balita yang tidak normal memiliki prosentase yang sama antara yang memiliki perkembangan sesuai dan tidak sesuai, sedangkan untuk status gizi normal mayoritas memiliki perkembangan yang sesuai. Mayoritas responden dengan pendapatan orang tua dan pendidikan yang tinggi memiliki status perkembangan sesuai sedangkan untuk jumlah saudara mayoritas responden dengan jumlah saudara 0-1 orang memiliki perkembangan yang sesuai.

Pada tahap uji regresi logistik diambil data dengan nilai $p<0,025$ sehingga ada 3 variabel yang diuji yaitu status gizi balita, pendidikan orang tua dan pendapatan orang tua. Pada tahap akhir uji ini diperoleh 2 variabel yang mempengaruhi status perkembangan balita yaitu status gizi balita dan pendidikan orang tua. Hasil uji regresi logistik dapat dilihat pada tabel 6.

Hasil uji statistik dengan regresi logistik menunjukkan bahwa pendidikan orang tua $(p=0,015)$ dan status gizi $(p=0,083)$ mempunyai pengaruh terhadap status perkembangan balita. Berdasarkan hasil uji di atas, pendidikan orang tua merupakan faktor yang paling berpengaruh terhadap status perkembangan balita. 
Tabel 2. Hubungan Beberapa Faktor dengan Status Perkembangan Balita

\begin{tabular}{|c|c|c|c|c|c|c|c|}
\hline \multirow{3}{*}{ Variabel } & \multicolumn{4}{|c|}{ Perkembangan Balita } & \multirow{2}{*}{\multicolumn{2}{|c|}{ Jumlah }} & \multirow{3}{*}{ p-value } \\
\hline & \multicolumn{2}{|c|}{ Tidak Sesuai } & \multicolumn{2}{|c|}{ Sesuai } & & & \\
\hline & $\mathrm{f}$ & $\%$ & $\mathrm{f}$ & $\%$ & $\mathrm{~F}$ & $\%$ & \\
\hline \multicolumn{8}{|c|}{ Berat Badan Lahir Balita } \\
\hline BBLR & 3 & 50 & 3 & 50 & 6 & 100 & \multirow{2}{*}{0,171} \\
\hline \multirow[t]{2}{*}{ Tidak BBLR } & 20 & 23,8 & 64 & 76,2 & 84 & 100 & \\
\hline & 23 & 25,6 & 67 & 74,4 & 90 & 100 & \\
\hline \multicolumn{8}{|l|}{ Status Gizi Balita } \\
\hline Tidak Normal & 8 & 50 & 8 & 50 & 16 & 100 & \multirow{2}{*}{0,024} \\
\hline \multirow[t]{2}{*}{ Normal } & 15 & 20,3 & 59 & 79,7 & 74 & 100 & \\
\hline & 23 & 25,6 & 67 & 74,4 & 90 & 100 & \\
\hline \multicolumn{8}{|c|}{ Pendapatan Orang Tua } \\
\hline Rendah & 14 & 40 & 21 & 60 & 35 & 100 & \multirow{2}{*}{0,024} \\
\hline \multirow[t]{2}{*}{ Tinggi } & 9 & 16,4 & 46 & 83,6 & 55 & 100 & \\
\hline & 23 & 25,6 & 67 & 74,4 & 90 & 100 & \\
\hline \multicolumn{8}{|c|}{ Pendidikan Orang tua } \\
\hline Rendah & 10 & 52,6 & 9 & 47,4 & 19 & 100 & \multirow{2}{*}{0,006} \\
\hline \multirow[t]{2}{*}{ Tinggi } & 13 & 18,3 & 58 & 81,7 & 71 & 100 & \\
\hline & 23 & 25,6 & 67 & 74,4 & 90 & 100 & \\
\hline \multicolumn{8}{|c|}{ Jumlah Saudara Balita } \\
\hline$>1$ & 5 & 38,5 & 8 & 61,5 & 13 & 100 & \multirow{2}{*}{0,305} \\
\hline \multirow[t]{2}{*}{$0-1$} & 18 & 23,4 & 59 & 76,6 & 77 & 100 & \\
\hline & 23 & 25,6 & 67 & 74,4 & 90 & 100 & \\
\hline
\end{tabular}

Perkembangan balita terbagi menjadi 4 aspek yaitu motorik kasar, motorik halus, kemampuan bicara dan bahasa serta sosialisasi dan kemandirian.[1] Setiap anak akan melewati proses tumbuh kembang sesuai dengan tahapan usianya. Akan tetapi, banyak faktor yang memengaruhi di antaranya faktor genetik dan lingkungan sejak prenatal, perinatal, dan postnatal. Faktor lingkungan adalah faktor yang menentukan tercapai atau tidaknya potensi bawaan yang terdiri atas lingkungan biopsikososial.[16]

Tabel 3. Analisis Multivariat dengan Uji Regresi Logistik

\begin{tabular}{|c|c|c|c|c|c|}
\hline \multirow[t]{2}{*}{ Variabel } & \multirow[t]{2}{*}{ Koef. $\beta$} & \multirow[t]{2}{*}{ p-value } & \multirow[t]{2}{*}{ PR } & \multicolumn{2}{|c|}{$\begin{array}{c}\text { Convidence Interval } \\
\text { (CI) } 95 \%\end{array}$} \\
\hline & & & & Upper & Lower \\
\hline Status Gizi Balita & 1,067 & 0,083 & 2,906 & 0,870 & 9,707 \\
\hline $\begin{array}{l}\text { Pendidikan Orang } \\
\text { Tua }\end{array}$ & 1,396 & 0,015 & 4,039 & 1,312 & 12,433 \\
\hline
\end{tabular}

\section{Hubungan Berat Badan Lahir dengan Perkembangan Balita Usia 1-3 Tahun}

Berat Badan Lahir Rendah (BBLR) adalah bayi dengan berat <2500 gram merupakan masalah kesehatan masyarakat utama yang secara negatif mempengaruhi perkembangan bayi dan kualitas hidup, serta menimbulkan beban keuangan pada sistem perawatan kesehatan.[17] Hasil uji chisquare menunjukkan nilai $p$-value $=0,171(>0,05)$ yang berarti tidak ada hubungan yang signifikan antara berat badan lahir dengan status perkembangan balita. Hal ini berbeda dengan hasil penelitian 
lain yang mengatakan bahwa anak yang lahir dengan riwayat berat badan lahir rendah memiliki kecenderungan untuk mengalami masalah perkembangan di kemudian hari. Hal tersebut disebabkan karena bayi dengan berat badan lahir rendah lebih rentan terhadap penyakit infeksi sehingga akan berdampak terhadap proses tumbuh kembangnya.[18]

Perkembangan balita sangat dipengaruhi oleh berat badan pada saat lahir. Anak yang lahir dengan BBLR berisiko untuk mengalami permasalahan perkembangan. Faktor eksternal seperti lingkungan dan stimulasi serta pola asuh dapat mengubah kondisi tersebut. Meskipun lahir dengan BBLR anak masih mempunyai kesempatan untuk tumbuh dan berkembang secara optimal jika faktor eksternal seperti stimulasi dan pola asuh diberikan secara maksimal. Penelitian ini sesuai dengan pernyataan tersebut yaitu anak yang lahir dengan berat badan rendah atau di bawah normal masih mempunyai kesempatan untuk berkembang secara normal sesuai dengan usia jika keluarga atau orang terdekat dapat memberikan stimulai maupun perawatan yang baik.[19]

\section{Hubungan Status Gizi Balita dengan Perkembangan Balita Usia 1-3 Tahun}

Faktor penting yang mempengaruhi tumbuh kembang anak adalah faktor gizi. Kekurangan gizi pada anak akan berdampak pada keterbatasan pertumbuhan, kerentanan terhadap infeksi, dan akhirnya dapat menghambat perkembangan sehingga anak perlu memperoleh gizi dari makanan dalam jumlah yang tepat dan kualitas baik.[20] Status gizi yang baik dapat bermanfaat untuk anak dalam menerima segala bentuk stimulasi yang diberikan.[21]

Hasil uji chi-square menunjukkan nilai $p$-value $=0,024(<0,05)$ yang berarti ada hubungan yang signifikan antara status gizi balita dengan status perkembangan balita usia 1-3 tahun. Hasil penelitian ini didukung oleh penelitian sebelumnya bahwa status gizi berpengaruh positif terhadap perkembangan balita dengan $p$-value 0,001 . Anak balita yang memiliki kecukupan gizi baik memiliki perkembangan yang lebih baik dibandingkan dengan anak balita dengan status gizi kurang maupun berlebih.(22) Status gizi berhubungan signifikan dengan perkembangan anak ( $p$-value $0,004)$. Status gizi yang buruk 5,7 kali lipat berisiko untuk terjadinya keterlambatan perkembangan. Status gizi yang buruk, berpotensi untuk terjadi perkembangan yang tidak sesuai dengan usia. Hal ini menjelaskan bahwa anak yang mengalami kekurangan makanan bergizi akan menyebabkan anak lemah dan tidak aktif sehingga dapat terjadi keterlambatan pertumbuhan dan perkembangan anak.[12]

\section{Hubungan Pendapatan Orang Tua dengan Perkembangan Balita Usia 1-3 Tahun}

Pendapatan keluarga yang memadai akan menunjang tumbuh kembang anak. Keluarga dengan pendapatan cukup memungkinkan orangtua memberikan alat permainan sebagai sarana stimulasi perkembangan anak. Status sosial ekonomi yang rendah dapat dilihat dari pendapatan keluarga yang rendah. Pendapatan rendah berpengaruh terhadap penyediaan makanan oleh keluarga terhadap anak.[23] Keluarga berpenghasilan rendah sering memiliki keterbatasan pendidikan, kurang kemampuan dalam merangsang perkembangan anak-anak mereka.[24] Hal ini akan mengabadikan siklus kemiskinan dan perkembangan anak yang buruk. Hasilnya pelestarian generasi selanjutnya dalam kemiskinan.[25]

Hasil uji chi-square menunjukkan nilai p-value $0,024(<0,05)$ yang berarti ada hubungan yang signifikan antara pendapatan orang tua dengan status perkembangan balita usia 1-3 tahun. Status sosial ekonomi rendah berhubungan secara signifikan dengan perkembangan anak balita, balita dengan status sosial ekonomi orang tua rendah memiliki peluang sebanyak 44 kali perkembangan anak balita tidak sesuai dengan tahapan usianya dibandingkan dengan balita yang status sosial ekonomi orang tuanya tinggi.[8] 


\section{Hubungan Pendidikan Orang Tua dengan Perkembangan Balita Usia 1-3 Tahun}

Hasil uji chi-square menunjukkan nilai $p$-value $0,006(<0,05)$ yang berarti ada hubungan yang signifikan antara pendidikan orang tua dengan perkembangan balita usia 1-3 tahun. Hasil penelitian ini didukung dengan penelitian yang menunjukkan bahwa balita dengan status pendidikan orang tua rendah memiliki peluang sebanyak 5 kali perkembangan anak balita tidak sesuai dengan tahapan usianya dibandingkan dengan balita yang status pendidikan orang tuanya tinggi dengan p-value 0,01.[14] Terdapat hubungan yang signifikan antara pendidikan orang tua dengan status perkembangan balita $p$-value 0,002 dan pendidikan orang tua yang rendah memiliki risiko 4,3 kali mengalami perkembangan yang tidak sesuai.[8]

Penelitian lain yang mendukung penelitian ini menunjukkan hubungan yang signifikan antara keterlambatan perkembangan dengan tingkat pendidikan orang tua dengan $p$-value 0,009.[26] Faktor pendidikan orang tua terutama ibu sangat berpengaruh dalam perkembangan anak balita, karena seorang ibu adalah subjek utama dalam pengasuhan anak. Seorang ibu dengan pendidikan rendah tidak mudah mengerti dan memahami kebutuhan anak dalam mendukung perkembangan anak sesuai tahapan usianya. Berbeda dengan orang tua yang berpendidikan tinggi, atau pengetahuan yang luas maka orang tua memahami bagaimana harus memposisikan diri dalam tahapan pekembangan anak.[9]

Tingkat perkembangan anak meningkat seiring dengan meningkatnya tingkat pendidikan ibu. Tingkat kecerdasan seorang anak pada usia dini menentukan arah hidup di masa dewasa. Oleh karena itu, semakin tinggi pengetahuan dan kapasitas orang tua untuk mendidik dan merawat anak mereka sejak usia dini, semakin tinggi kemungkinan orang tua bisa memberikan berbagai rangsangan yang akan mempercepat perkembangan kecerdasan anak mereka.[27]

\section{Hubungan Jumlah Saudara Balita dengan Perkembangan Balita Usia 1-3 Tahun}

Jumlah anak yang banyak pada keluarga yang keadaan sosial ekonominya cukup akan mengakibatkan berkurangnya perhatian dan kasih sayang yang diterima anak, selain kebutuhan dasar anak juga tidak terpenuhi. Sehingga akan berdampak pada tumbuh kembang anak.[2] Studi penelitian di kota Dhaka pada 249 anak ada hubungan yang signifikan antara jumlah jumlah anak dalam keluarga dengan perkembangan anak.[28] Hasil penelitian yang dilakukan di Istanbul menunjukkan adanya hubungan yaitu jumlah anak dalam keluarga $>2$ berisiko 1,909 kali mengalami keterlambatan perkembangan. Banyaknya jumlah anak dalam keluarga membuat perhatian orang tua terbagi dan kurang maksimal pada masing-masing anak.[29] Faktor risiko memiliki $\geq 3$ anak dalam keluarga berhubungan dengan keterlambatan perkembangan pada balita. Jumlah anak $\geq 3$ dalam keluarga berisiko 1,87 kali mengalami keterlambatan perkembangan.[13]

Tidak ada hubungan yang signifikan antara jumlah saudara balita dengan status perkembangan balita. Hasil penelitian ini sejalan dengan penelitian lain menyatakan bahwa tidak ada hubungan bermakna antara jumlah saudara dan perkembangan anak $(p=0,128)$. Hasil penelitian tidak bermakna dapat disebabkan oleh pemerataan pemenuhan kebutuhan kasih sayang dan perhatian sehingga setiap aspek perkembangan dapat berjalan dengan baik.[30]

\section{Kesimpulan}

Ada hubungan faktor status gizi balita, pendapatan orang tua, dan pendidikan orang tua dengan status perkembangan balita usia 1-3 tahun. Faktor berat badan lahir balita dan jumlah saudara balita tidak ada hubungan dengan status perkembangan balita usia 1-3 tahun. Pendidikan orang tua yang merupakan faktor paling mempengaruhi status perkembangan balita usia 1-3 tahun. 


\section{Ucapan Terimakasih}

Ucapan terima kasih disampaikan kepada Kepala Puskesmas Gamping II dan staf serta semua pihak terkait yang telah mendukung dan membantu dalam proses pelaksanaan sehingga penelitian ini dapat diselesaikan dengan baik.

\section{Referensi}

[1]. Kemenkes RI. Pedoman Pelaksanaan Stimulasi,Deteksi dan Intervensi Dini Tumbuh Kembang Anak di Tingkat Pelayanan Kesehatan Dasar. Jakarta: Kemenkes RI; 2015.

[2]. Soetjiningsih dan Ranuh. Tumbuh Kembang Anak. Jakarta: EGC; 2015.

[3]. UNICEF. Inequities in Early Childhood Development: What the data say. Evidence from the Multiple Indicator Cluster Surveys. 2012;20. Available from: https://www.unicef.org/publications/files/Inequities_in_Early_ Childhood_Development_LoRes_PDF_EN_02082012.pdf

[4]. UNICEF. Investasi pada Perkembangan Anak Usia Dini Penting untuk Membantu Anak dan Masyarakat, Temuan Lancet Series. 2016.

[5]. Wilar R, Lestari H. Faktor-faktor yang mempengaruhi keterlambatan perkembangan anak taman kanak-kanak. e-Clinic (eCI) [Internet]. 2015;3(1):124-32. Available from: http://id.portalgaruda.org/?ref=browse \&mod=viewarticle\&article=291797

[6]. Wong, D.L., Eaton, M.H., Wilson, D., Winkelstein, M.L., \& Schwartz P. Buku Ajar Keperawatan Pediatrik. Jakarta: EGC; 2009.

[7]. IDAI. Mengenal Keterlambatan Umum pada Anak. 2013; Available from: http://www.idai.or.id/artikel/seputar-kesehatan-anak/mengenal-keterlambatanperkembangan-umum-pada-anak

[8]. Lestari RD, Isa N, Novadela T. Faktor postnatal yang berhubungan dengan perkembangan anak balita di wilayah lampung utara. 2016;XII(2):219-27.

[9]. Lovena A. Hubungan antara Perkembangan Sosial Anak terhadap Hasil Belajar Bahasa Indonesia Siswa Kelas IV/B SD Negeri 65 Kota Bengkulu. Fak Kegur dan Ilmu Pendidik Univ Bengkulu. 2013;

[10]. Atiqoh RN. Hubungan Prematuritas dan BBLR dengan Kejadian Gangguan Perkembangan Balita di RSUP DR. Sardjito Tahun 2016. Universitas Gadjah Mada; 2016.

[11]. Dinkes Sleman. Profil Kesehatan Kabupaten Sleman Tahun 2015. Sleman: Dinkes Sleman; 2016.

[12]. Lindawati. Faktor-Faktor yang Berhubungan Dengan Perkembangan Motorik Anak Usia Pra Sekolah. J Heal Qual [Internet]. 2012;4(1):1-76. Available from: http://www.poltekkesjakarta1.ac.id/file/dokumen/46 JURNAL_LINDAWATI.pdf

[13]. M Ozkan, S Senel, EA Arslan CK. The Socioeconomic and Biological Risk Factors for Developmental Delay In Early Childhood. Eur J Pediatr. 2012;171(12):1815-21.

[14]. Bhattacharya T, Ray S, Das DK. Developmental Delay Among Children Below Two Years of Age :A Cross- Sectional Study in A Community Development Block of Burdwan District , West Bengal. International Journal of Community Medicine and Public Health. 2017;4(5):1762-7.

[15]. Widiaskara LGAPV dan Windiani IGAT. Prevalens Keterlambatan Perkembangan Anak. E-Jurnal Med. 2017;6(9):34-7.

[16]. Usman H, Sukandar H, Sutisna M, Kebidanan J, Kesehatan P, Kesehatan K, et al. 
Pertumbuhan dan Perkembangan Anak Usia 3-24 Bulan di Daerah Konflik. Kesmas Jurnal Kesehatan Masyarakat Nasional. 2014;(13).

[17]. Tavasoli A, Aliabadi F, Eftekhari R. Motor Developmental Status of Moderately Low Birth Weight Preterm Infants. Iranian Journal of Pediatrics. 2014;24(5):581-6.

[18]. Scharf RJ, Stroustrup A CM. Growth and development in children born very low birthweight Archives of Disease in Childhood. Fetal Neonatal Ed. 2016;344(6188):1173-8.

[19]. Linsell, Malouf R, Morris J, JJ K, Marlow N. Prognostic factors for poor cognitive development in children born very preterm or with very low birth weight: A systematic review. JAMA Pediatr. 2015;169(12):1162-72.

[20]. Rosela E, Hastuti TP, Triredjeki H. Hubungan Status Gizi Dengan Perkembangan Anak Usia 1 sampai 5 Tahun Di Kelurahan Tidar Utara, Kota Magelang. J Keperawatan Soedirman (The Soedirman J Nursing). 2017;12(1):27-37.

[21]. Solihin DM, Faisal A, Dadang S. Kaitan Antara Status Gizi,Perkembangan Kognitif, Dan Perkembangan Motorik Pada Anak Usia Prasekolah. Penelit Gizi dan Makanan. Notrition and Food Research. 2013;36(1):62-72.

[22]. Kusuma IR, Salimo H, Sulaeman ES. Analisis pengaruh berat badan lahir rendah, pemberian ASI eksklusif, stimulasi dan status gizi terhadap perkembangan motorik kasar anak usia 6-24 bulan di kabupaten banyumas. Semin Nas Kebidanan [Internet]. 2017;1(1):321-7. Available from: http:/eprosiding.unw.ac.id/index.php/snk/article/view/43

[23]. Wulandari UR, Budihastuti UR, Pamungkasari EP. Analysis of Life-Course Factors Influencing Growth and Development in Children under 3 Years Old of Early Marriage Women in Kediri. Journal of Maternal and Child Health. 2014;257:137-49.

[24]. Engle, Patrice L and Black MM. The Effect of Poverty on Child Development. Annals of The New York Academy of Sciences. 2008;1136:243-256

[25]. Ali SS. A Brief Review of Risk - Factors for Growth and Developmental Delay Among Preschool Children in Developing Countries. Biomedical Research. 2013;2(4).

[26]. Westgard C, Alnasser Y. Developmental Delay in The Amazon: The Social Determinants and Prevalence Among Rural Communities in Peru. Plos One. 2017;1-13.

[27]. Warsito O, Khomsan A, Hernawati N, Anwar F. Relationship between nutritional status, psychosocial stimulation, and cognitive development in preschool children in Indonesia. Nutr Res Pract. 2012;6(5):451-7.

[28]. Tofail F, Hamadani JD, Ahmed AZT, Mehrin F, Hakim M, Huda SN. The Mental Development and Behavior of Low-Birth-Weight Bangladeshi Infants From An Urban Low-Income Community. Eur J Clin Nutr [Internet]. 2012;66(2):237-43. Available from: http://dx.doi.org/10.1038/ejcn.2011.165

[29]. Çelikkiran S, Bozkurt H, Coskun M. Denver Developmental Test Findings and their Relationship with Sociodemographic Variables in a Large Community Sample of 0-4-YearOld Children. Noro Psikiyatr Ars [Internet]. 2015;52(2):180-4. Available from: http://www.noropsikiyatriarsivi.com/sayilar/429/buyuk/180-184.pdf

[30]. Tilaar SKI, Runtunuwu AL. Faktor-faktor yang berhubungan dengan keterlambatan perkembangan bayi usia 9 bulan. Jurnal e-clinic. 2016;4:2-7. 